Brazilian Journal

of Chemical

Engineering

\title{
EFFECT OF ALUMINUM SULFATE AND CATIONIC POLYMER ADDITION IN THE MIXED LIQUOR OF A SUBMERGED MEMBRANE BIOREACTOR (SMBR): SLUDGE CHARACTERISTICS AND ORTHOPHOSPHATE REMOVAL IN BATCH EXPERIMENTS
}

\author{
Jamile Gonçalves ${ }^{1}$, Aldrew A. Baldovi ${ }^{1}$, Bruna Chyoshi ${ }^{1}$, Leonardo Zanata ${ }^{1}$, \\ Alvaro M. Salcedo ${ }^{1}$, Eduardo L. Subti $1^{*}$ and Lúcia H. G. Coelho ${ }^{1}$ \\ ${ }^{1}$ Universidade Federal do ABC, Centro de Engenharia, Modelagem e Ciências Sociais Aplicadas, Santo André, SP, Brasil. \\ ORCID: 0000-0001-7148-2519; ORCID: 0000-0002-0850-7901; ORCID: 0000-0001-5357-5148; ORCID: 0000-0003-1209-6428; \\ E-mail: eduardo.subtil@ufabc.edu.br - ORCID: 0000-0003-3674-2674; ORCID: 0000-0002-0175-5734
}

(Submitted: March 29, 2018 ; Revised: September 11, 2018 ; Accepted: October 1, 2018)

\begin{abstract}
Submerged Membranes Bioreactors (SMBR) are an established technology for wastewater treatment for water recovery and reuse. However, its routine application is still compromised by the high energy consumption to overcome the fouling effect. This study evaluated the effect of aluminum sulfate and cationic polymer in the orthophosphate removal and sludge filterability improvement in the mixed liquor of a SMBR pilot system. Parameters such as coagulant concentration, filtration time, extracellular polymeric substances (EPS) reduction and orthophosphate removal were evaluated by using a jar-test and a stirred cell. As results, aluminum sulfate and polymer additions improved the filtration index $\left(\mathrm{FI}_{30}\right)$ from $25 \%$ to $32 \%$, for both chemicals. Timeto-filter (TTF) results evidenced a positive and significant correlation between aluminum sulfate dosage and colloidal EPS reduction.
\end{abstract}

Keywords: Advanced effluent treatment; Coagulation; Foulants; Fouling reduction; Membrane.

\section{INTRODUCTION}

The world's population is increasing fast and it is estimated that by 2050 it will reach more than 6.4 billion people living in urban areas. Meanwhile, $40 \%$ of this population will be affected by water shortage and loss in quality (Schlosser et al., 2014). The implications for planning and managing water resources are complex, with the potential to destabilize the world economy, given the intrinsic relationship between water-energyfood interfaces. In this interdisciplinary context, the effluents to be treated in wastewater treatment plants (WWTP) deserve special attention and can no longer be seen as a waste, but as a valuable resource, worthy of recovery and reuse (Subtil et al., 2016; Verstraete et al., 2016).

Novelty in water recovery and reuse technology solutions can offer appropriate options to ensure that cities are resilient to droughts and challenges of increasing water shortage. Despite the huge number of wastewater treatment technologies developed in recent decades, the Membrane Bioreactor (MBR) plays an important role in water recovery and reuse alternatives in urban areas. The MBR technology, which combines a biological and a physical separation process (mainly using micro and ultrafiltration membranes - MF and UF) became a reliable and efficient alternative to be applied in urban wastewater

\footnotetext{
* Corresponding author: Eduardo Subtil - E-mail: eduardo.subtil@ufabc.edu.br
} 
treatment and water reuse (Le-Clech, 2010; Subtil et al., 2014).

MBR systems explore the high separation capacity of membranes to remove the biomass, allowing system operation from low to high biomass concentration as Mixed Liquor Suspended Solids (MLSS) (8 - 15 g MLSS.L ${ }^{-1}$ ) and also with a high range of solids retention time (SRT) (10 - 30 days) when operating on a full-scale system, resulting in a high-quality effluent (ideal for water reuse), as well as a system with reduced implantation area, up to $40 \%$ smaller compared to the conventional activated sludge arrangement (Judd, 2006; Subtil et al., 2013; Karim \& Mark, 2017).

Despite the intrinsic advantages of the MBR system, its common application is still compromised by the energetic consumption of air scouring as a necessary means for fouling control (Krzeminski et al., 2017). Fouling in MBR processes, which results from the interaction between the mixed liquor and the membrane separation process, can compromise the treatment performance by reducing the filtration flux in the membranes, requiring more frequent cleanups, and even membrane replacement in the worst clogging condition (Wang et al, 2014; Krzeminski et al., 2017).

According to Wang et al. (2009), many substances compose the organic fraction of (bio)chemical species that causes fouling. Among them, the Extracellular Polymeric Substances (EPS), which are mainly proteins and polysaccharides produced by the flocforming biomass in activated sludge systems, are formed as a product of microorganism metabolism. The EPS are mainly divided into two groups: soluble EPS (EPS) or supernatants, which is the fraction dispersed in the supernatant and; bound EPS (EPS $)$, which is the fraction adhered to the biomass cells. The EPS are described as the major contributors to fouling in membrane bioreactors (Zhang et al., 2015).

Among the methods used to minimize the fouling, the use of activated carbon (AC) and other supporting materials resulted in fouling control through mechanical scouring (physical cleaning effect) (Subtil et al., 2014; Iorhemen et al., 2016). Moreover, Remy et al. (2010) demonstrated that powdered activated carbon (PAC) in very low dosages reduces membrane fouling not only by enhanced scouring of the membrane surface, but also due to adsorption of membrane foulants by PAC with subsequent biodegradation, causing a positive effect on the strength of the sludge flocs. However, these strategies can damage the membrane structure, depending on the abrasiveness, size and amount of the scouring material used (Wu et al., 2017).

Besides the use of supporting material, the addition of aluminum and iron-based coagulants in the wastewater treatment is able to improve the mixed liquor filtration characteristics, as well as benefit the removal of phosphorus, soluble organic matter and colloidal substances (Song et al., 2008; Mishima \& Nakajima, 2009; Yigit et al., 2010; Teychene et al., 2011; Koseoglu et al., 2012; Huyskens et al., 2012; Gkotsis et al., 2014; Iorhemen et al., 2016).

The improvement of the sludge filterability condition of the mixed liquor by the addition of metallic salts is generally associated with colloidal substances and floc charge neutralization, resulting in fouling reduction (Lee et al. 2001; Wu et al. 2006). According to the divalent cation bonding theory, metallic salts can bond to negatively charged functional groups inside the EPS, which also promotes an enhancement in the size, density and shearing resistance of the flocs (Zang et al., 2008). However, the use of metallic coagulants based on aluminum salts in concentrations above $0.36 \mathrm{mmol} \mathrm{L}^{-1}$, at $\mathrm{pH}$ values between 6 to 8 , can promote an excessive formation of aluminum hydroxide precipitates and, as a consequence, $\mathrm{H}^{+}$ ions are released to the solution, lowing the bulk $\mathrm{pH}$ (Macêdo, 2007; Mbaeze et al., 2017).

Wu et al (2006) demonstrated a positive correlation between coagulants and flocculant addition (separately) to the mixed liquor of the MBR, and reduction in the dissolved organic carbon and filterability enhancement using metallic salts and polyacrylamide. Khan et al. (2012) obtained a flux improvement using a cationic polyacrylamide. Both studies agreed that the enhancement of the flux attributed to the use of polyacrylamides depends on the design and operating conditions of the system, as well as on the affluent characteristics and chosen coagulant quantity to avoid colloidal destabilization. Conversely, Chen et al. (2017) used the coagulation technique associated with an ultrasound treatment to improve EPS retention on the flocs. These different approaches suggest that there still is a gap in which fouling associated substances, $\mathrm{EPS}_{\mathrm{s}}$ or $\mathrm{EPS}_{\mathrm{b}}$, are affected by the coagulants, leading to an improvement in the filterability properties of the mixed liquor associated with the improvement in phosphorus removal.

Although some studies have been developed with coagulants and flocculants to improve the mixed liquor characteristics, their application in real sludge from MBR is scarce and comparisons between flux enhancers (coagulants and flocculants) are a novelty. In this context, the aim of this work was to compare, through batch experiments, the effect of aluminum sulfate $\left(\mathrm{Al}_{2}\left(\mathrm{SO}_{4}\right)_{3}\right)$ and a high molecular weight cationic polyacrylamide on the properties of mixed liquor from a SMBR pilot plant fed with a domestic wastewater. The experiments were carried out using the jar-test and a stirred-cell where the reduction of soluble and bound EPS fractions, colloidal carbon, orthophosphate and filterability were evaluated. 


\section{MATERIAL AND METHODS}

\section{Reagents}

A $10 \% \quad(\mathrm{w} / \mathrm{v}) \quad 98 \%$ pure aluminum sulfate $\left(\mathrm{Al}_{2}\left(\mathrm{SO}_{4}\right)_{3} .18 \mathrm{H}_{2} \mathrm{O}, 666.5 \mathrm{~g} \cdot \mathrm{mol}^{-1}\right)$ (Dinamica, Brazil) solution was prepared as coagulant and a $1 \%(\mathrm{w} / \mathrm{v})$ 99\% pure Basf Zetag ${ }^{\circledR} 8127$ high molecular weight $\left(10.000\right.$ g.mol $\left.{ }^{-1}\right)$ cationic polymer was prepared as flocculant (this solution was prepared $24 \mathrm{~h}$ before the essays to provide proper chain opening time to the polymer). A solution $0.9 \%(\mathrm{w} / \mathrm{v})$ of $99 \%$ pure $\mathrm{NaCl}$ (Dinamica, Brazil) solution was prepared as EPS $_{b}$ extraction solution.

\section{Mixed liquor samples - Submerged Membrane Bioreactor pilot-plant}

The sludge used in this study was obtained from a Submerged Membrane Bioreactor (SMBR) pilot plant $(156 \mathrm{~L})$ which was continuously fed with domestic wastewater from the student housing and restaurant of the University of São Paulo (São Paulo - Brazil). Prior to the SMBR system, wastewater came from a mechanical screening (step-screen) and grit chamber. The SMBR was equipped with a real-time data acquisition system for flow, temperature, pressure, Oxidation Reduction Potential (ORP), dissolved oxygen (DO) and $\mathrm{pH}$ monitoring (Figure 1). A flat sheet ultrafiltration membrane module (FS-UF) from SINAP ${ }^{\circledR}$ was used for solid separation. The membrane was synthesized in polyvinylidene fluoride (PVDF) with a mean pore size of approximately $0.1 \mu \mathrm{m}$ and total membrane area of $1.7 \mathrm{~m}^{2}$ (17 membrane flat sheet plates module).

During the study period, the pilot plant was maintained under ambient temperature and operated with conventional standards, in which the DO concentration was maintained above $2.0 \mathrm{mg} \mathrm{L}^{-1}$. The main operational parameters of the SMBR are shown in Table 1.

\section{Chemical dosage procedure}

The chemical dosage procedure using coagulant and flocculant addition to the SMBR mixed liquor was carried out in the batch operation mode through a Jar Test equipment (Policontrol ${ }^{\circledR}$, model FlocControl II), on a single batch of experiments. For each experiment, four different concentrations of coagulant and polymer were used separately, as presented in Table 2. It is important to highlight that one of the flasks was used as control (mixed liquor only). The substance concentrations were defined taking into account the studies of Tchobanoglous et al. (2003),

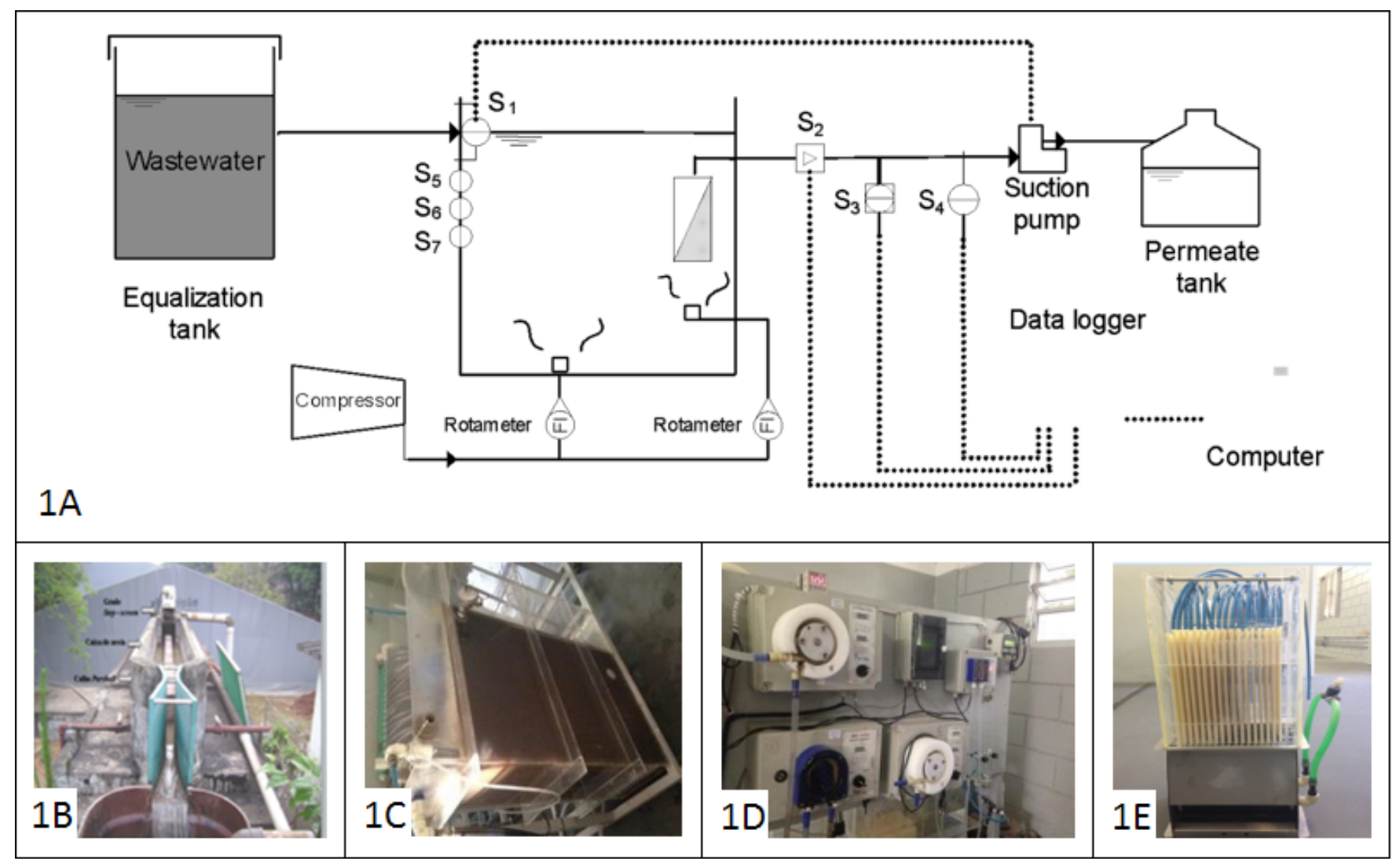

Figure 1. General view of the experimental SMBR pilot plant: 1A - Flowchart of the pilot plant,: $\mathrm{S}_{1}$ - level sensor; $\mathrm{S}_{2}$ - permeate flow sensor; $\mathrm{S}_{3}$ - pressure sensor; $\mathrm{S}_{4}$ - temperature sensor; $\mathrm{S}_{5}$ - DO probe; $\mathrm{S}_{6}$ - $\mathrm{pH}$ sensor and; $\mathrm{S}_{7}$ - ORP sensor, 1B - preliminary treatment; 1C - Membrane Bioreactor; 1D - Control Panel; 1E - Membrane Cassette. 
Table1. SMBR operational parameters.

\begin{tabular}{|c|c|c|}
\hline Parameters & Average & Unit \\
\hline Dissolved oxygen & $2.51 \pm 0.29$ & $\mathrm{mg} \mathrm{L}^{-1}$ \\
\hline ORP & $212 \pm 69$ & $\mathrm{mV}$ \\
\hline Temperature & $23.8 \pm 0.7$ & ${ }^{\circ} \mathrm{C}$ \\
\hline Transmembrane Pressure (TMP) & $0.016 \pm 0.004$ & bar \\
\hline Flow rate & $22.1 \pm 1.8$ & L.h $^{-1}$ \\
\hline $\mathrm{pH}$ & $6.83 \pm 0.22$ & - \\
\hline Flux & $13.0 \pm 1.3$ & L.m $\mathrm{m}^{-2} \cdot \mathrm{h}^{-1}$ \\
\hline Permeability & 828 & $\mathrm{~L} \cdot \mathrm{m}^{-2} \cdot \mathrm{h}^{-1} \cdot$ bar $^{-1}$ \\
\hline Solids Retention Time (SRT) & 22 & days \\
\hline Mixed Liquor Suspended Solids (MLSS) & $4876 \pm 950$ & $\mathrm{mg} \mathrm{L}^{-1}$ \\
\hline Mixed Liquor Volatile Suspended Solids (MLVSS) & $4396 \pm 902$ & $\mathrm{mg} \mathrm{L}^{-1}$ \\
\hline
\end{tabular}

Table 2. Molar and mass concentrations of coagulant and polymer used in the Jar test experiments.

\begin{tabular}{lcccccc}
\hline \multicolumn{1}{c}{ Substance } & \multirow{2}{*}{ Unit } & \multicolumn{5}{c}{ Jar-test (sample) } \\
\cline { 5 - 7 } & & $\mathbf{0}$ & $\mathbf{1}$ & $\mathbf{2}$ & $\mathbf{3}$ & $\mathbf{4}$ \\
\hline \multirow{2}{*}{$\mathrm{Al}_{2}\left(\mathrm{SO}_{4}\right)_{3} .18 \mathrm{H}_{2} \mathrm{O}$} & $\mu \mathrm{mol} \mathrm{L}^{-1}$ & 0 & 0.6 & 1.8 & 3.6 & 5.5 \\
\multirow{2}{*}{$\mathrm{HMW}$ Cationic Polyacrylamide Polymer } & $\mathrm{mg} \mathrm{L}^{-1}$ & 0 & 50 & 150 & 300 & 450 \\
& $\mathrm{nmol} \mathrm{L}$ & 0 & 0.5 & 1.0 & 1.5 & 2.0 \\
\hline
\end{tabular}

Song et al. (2008) and Koseoglu et al. (2012). Jar Test experiments were performed for 15 minutes at a speed of $110 \mathrm{rpm}$ for the first 5 minutes (mixing step) and then reduced to $50 \mathrm{rpm}$. The $\mathrm{pH}$ was monitored with a calibrated $\mathrm{pH}$ meter (New Instruments ${ }^{\circledR}$, model NI PHN). For each experimental condition, analyses of MLSS, filterability, EPS and orthophosphate were carried out.

\section{Flux enhancement experiments}

Time to Filter (TTF) determination

The TTF tests were based on the method described in the Standard Methods for Examination of Water and Wastewater 2710 H (APHA, 2012), which correlates filtering time with capillary suction time. The experiment consisted of placing $100 \mathrm{~mL}$ of the sludge sample in a Büchner funnel with a paper support filter $(1.2 \mu \mathrm{m})$, applying a constant vacuum of $51 \mathrm{kPa}$ and measuring the time required for $50 \mathrm{~mL}$ of filtrate $(50 \%$ of the original sample volume). The TTF (in seconds) is given by Equation 1:

$\mathrm{TTF}=\frac{\text { Filtration time }(\mathrm{s})}{\operatorname{MLSS}\left(\mathrm{g} \mathrm{L}^{-1}\right)}$

Resistance in series model tests and Fouling Index (FI30)

Resistance in series model tests was determined as described by Park et al. (2015) using a stirred cell (model Amicon 8400) (Figure 2). During the experiments the pressure was maintained constant at 1.0 bar. In this model, total resistance $\left(\mathrm{R}_{\mathrm{T}}\right)$ includes both membrane resistance $\left(\mathrm{R}_{\mathrm{M}}\right)$ and fouling resistance $\left(R_{F}\right)$, which is composed by resistance of the cake layer $\left(R_{C}\right)$ and adsorbed resistance $\left(R_{A}\right.$ - includes

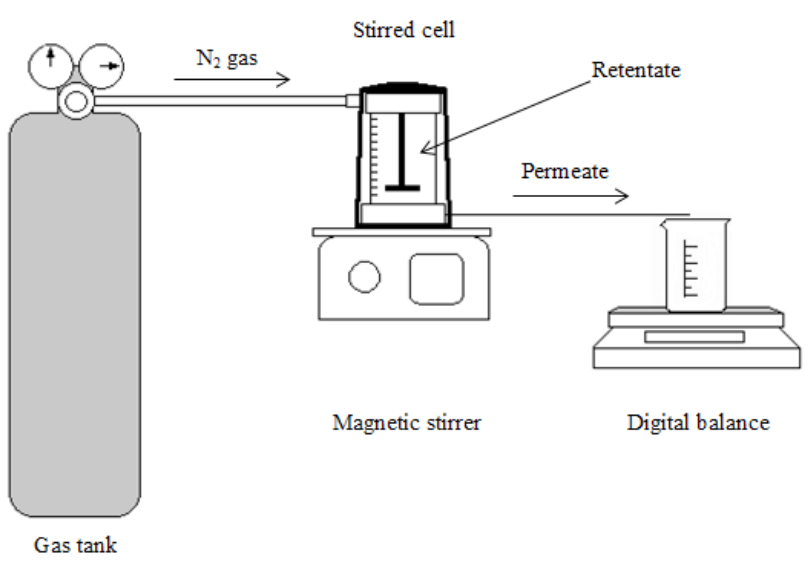

Figure 2. Schematic diagram of the experimental setup.

adsorption and pore blocking resistance). For the same membrane sample, filtration with ultrapure water was carried out followed by mixed liquor filtration and finally by cleaning of the cake layer and filtration with ultrapure water again. The hydraulic resistance for each filtration was determined based on Darcy's law following Equations 2 and 3. After this, the membranes were chemically cleaned with $200 \mathrm{mg} . \mathrm{L}^{-1}$ sodium hypochlorite and sodium hydroxide solution at $\mathrm{pH} 12$. The entire filtration procedure was carried out three times for each sample with the same membrane. The aluminum sulfate test was performed at a concentration of $300 \mathrm{mg} . \mathrm{L}^{-1}$, while the cationic polymer was dosed at a concentration of $200 \mathrm{mg} \mathrm{L}^{-1}$. The fouling index was calculated by dividing the observed flux after $30 \mathrm{~min}$ of filtration, $\mathrm{J}_{30}$, by the initial water flux, $\mathrm{J}_{\mathrm{w} 0}$.

$\mathrm{J}=\frac{\Delta \mathrm{P}}{\mu\left(\mathrm{R}_{\mathrm{m}}+\mathrm{R}_{\mathrm{C}}+\mathrm{R}_{\mathrm{A}}\right)}$ 


$$
\mathrm{R}=\frac{\mathrm{TMP}}{\eta \cdot \mathrm{J}}
$$

where $\mathrm{J}$ is the flux through the membrane $\left(\mathrm{m} \mathrm{s}^{-1}\right)$, Q the flux rate $\left(\mathrm{m}^{3} . \mathrm{s}^{-1}\right)$, A the membrane area $\left(\mathrm{m}^{2}\right)$, TMP the transmembrane pressure $(\mathrm{Pa}), \eta$ the dynamic viscosity (Pa.s) and $\mathrm{R}$ the membrane hydraulic resistance $\left(\mathrm{m}^{-1}\right)$.

Analysis of Extracellular Polymeric Substances (EPS)

The amount of EPS from the SMBR mixed liquor was extracted according to the method developed by Morgan et al. (1990) and described in detail by Judd (2006). The extracted EPS was quantified as organic carbon (total, colloidal and dissolved) as presented in Figure 3. A $100 \mathrm{~mL}$ sample was taken from the raw mixed liquor after each treatment condition (aluminum sulfate and cationic polymer concentrations) and centrifuged at $3000 \mathrm{rpm}$. The supernatant of the first centrifuged sample was filtered through a $1.2 \mu \mathrm{m}$ glass fiber filter (Analítica $\AA$, Brazil) and the obtained filtrate was considered as total soluble EPS $\left(\mathrm{EPS}_{\mathrm{ST}}\right)$. Further filtration of the supernatant was performed with a 0.45 $\mu \mathrm{m}$ cellulose filter (Analítica ${ }^{\circledR}$, Brazil), resulting in the dissolved EPS $\left(\mathrm{EPS}_{\mathrm{SD}}\right)$, that was only used to calculate the colloidal fraction of EPS (EPS $\mathrm{SC}_{\mathrm{SC}}$ ), by subtraction from $\mathrm{EPS}_{\mathrm{ST}^{*}}$ In this study, the colloidal EPS was classified as the particles between 0.45 and $1.2 \mu \mathrm{m}$. Although it does not include all colloidal substances, it has been known as a good indicator of membrane fouling potential in MBR in many different locations (YOON, 2015).

To extract the bound EPS fraction $\left(\mathrm{EPS}_{\mathrm{BT}}\right.$ and $\mathrm{EPS}_{\mathrm{BD}}$ ) from the sludge and to calculate the bound colloidal EPS $\left(\mathrm{EPS}_{\mathrm{BC}}\right)$, the remaining centrifuged sludge was bulked with $0.9 \%$ (w/v) $\mathrm{NaCl}$ solution, heated at $100^{\circ} \mathrm{C}$ for $1 \mathrm{~h}$ and centrifuged again. Thus, the second supernatant extraction followed the same methodology as the soluble EPS.

After the extraction, Total Organic Carbon (TOC) was determined (Shimadzu, model TOC-L) with replicate readings. The bonded EPS extraction was carried out using a SL-700 centrifuge and a SL-100 heating oven, both from Solab laboratory equipment. The bonded and soluble EPS, as well the TTF determination, were normalized to the MLSS concentration.

\section{Analytical methods}

The parameters evaluated in the experiment are presented in Table 3.

\section{Statistical analysis}

To analyze the correlation between the variables

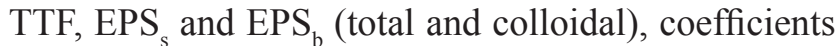
were calculated using the Pearson correlation method (p). The coefficient can take a range of values from +1 to -1 and indicates the magnitude of correlation between the variables. In this study, $\mathrm{p}>0.9$ was considered a strong linear correlation coefficient.

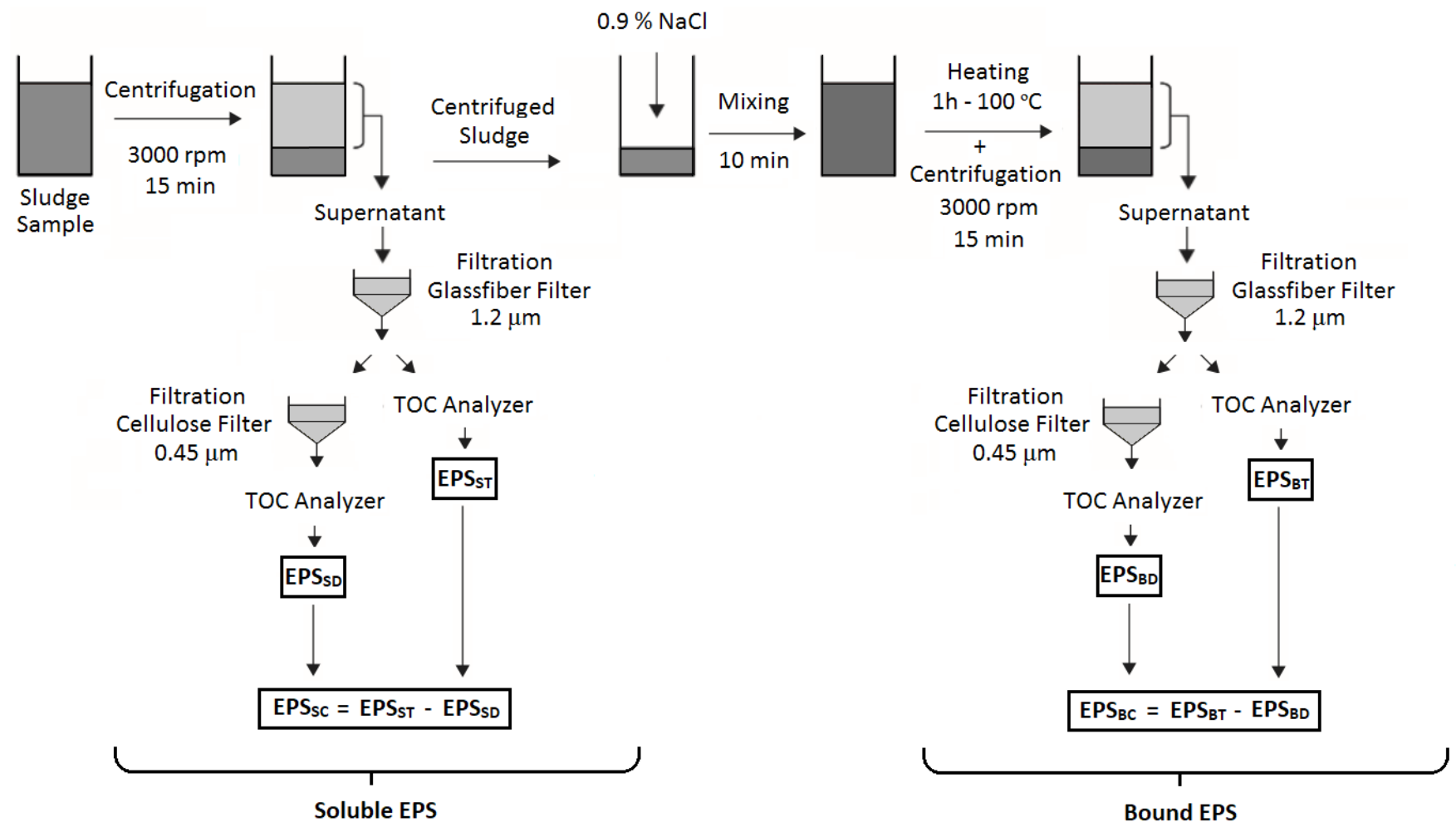

Figure 3. EPS extractions methodology from SMBR mixed liquor. 
Table 3. Evaluated parameters and methodologies.

\begin{tabular}{lcc}
\hline \multicolumn{1}{c}{ Parameter } & Unit & Method \\
\hline Biochemical oxygen demand (BOD, 20$)$ & $\mathrm{mg} \mathrm{O}_{2} \mathrm{~L}^{-1}$ & 5210-D - APHA (2012) \\
Chemical oxygen demand (COD) & $\mathrm{Mg} \mathrm{O}_{2} \mathrm{~L}^{-1}$ & 5220-D - APHA (2012) \\
TOC & $\mathrm{mg} \mathrm{C} \mathrm{L}^{-1}$ & 5310 - APHA (2012) \\
MLSS & $\mathrm{mg} \mathrm{L}^{-1}$ & 2540-D - APHA (2012) \\
MLVSS & $\mathrm{mg} \mathrm{g}^{-1}$ & $2540-\mathrm{E}-\mathrm{APHA}(2012)$ \\
Orthophosphate & $\mathrm{mg} \mathrm{PO}^{3-} \mathrm{L}^{-1}$ & $12772 \mathrm{~A}-\mathrm{ABNT}-\mathrm{NBR}(1992)$ \\
\hline
\end{tabular}

\section{RESULTS AND DISCUSSION}

\section{SMBR performance}

The results of SMBR performance are presented in Table 4, in which it is possible to observe $\mathrm{BOD}_{5,20}$ and COD removal of $96 \%$ and $95 \%$, respectively. The high removal of organic matter by SMBR is associated with the membrane separation capacity, since they represent an absolute barrier to the suspended solids, avoiding the solid matter escape with the supernatant effluent. Besides, the membrane partition enables organic compounds of greater molecular weight to be retained in the reactor, allowing higher retention time and biodegradation of the compounds by microorganisms in the biomass. During the experiments, the concentration of MLSS ranged from $3523 \mathrm{mg} \mathrm{L}^{-1}$ to $5432 \mathrm{mg} \mathrm{L}^{-1}$.

Table 4. SMBR effluent and permeate characterization.

\begin{tabular}{lccc}
\multicolumn{1}{c}{ Parameters } & Wastewater & Permeate & $\begin{array}{c}\text { Removal } \\
(\mathbf{\%})\end{array}$ \\
\hline $\mathrm{BOD}_{5,20}\left(\mathrm{mg} \mathrm{O}_{2} \cdot \mathrm{L}^{-1}\right)$ & $142 \pm 27$ & $5.1 \pm 2.1$ & 96 \\
$\mathrm{COD}\left(\mathrm{mg} \mathrm{O}_{2} \cdot \mathrm{L}^{-1}\right)$ & $480 \pm 197$ & $19.9 \pm 7.6$ & 95 \\
Total Phosphorus & $4.3 \pm 0.9$ & $3.1 \pm 0.6$ & 30 \\
$\left(\mathrm{mg} \mathrm{PO}_{4}^{3-} \cdot \mathrm{L}^{-1}\right)$ & & \\
\hline
\end{tabular}

\section{Effect of coagulant and flocculant in the mixed liquor}

In this study, the parameter used to evaluate improvements in the sludge characteristics was TTF, which was primarily developed to measure sludge dewaterability. Despite this, several studies have used TTF to compare the potential effect of different conditions on improving sludge filterability (Fan, et al., 2006; Côté 2007; Gkotsis et al., 2017).

Figure 4 summarizes the TTF index determined in this study as a function of aluminum sulfate and cationic polyacrylamide concentrations. An important reduction in TTF index was observed due to $\mathrm{Al}_{2}\left(\mathrm{SO}_{4}\right)_{3}$, mainly when the dose of coagulant was between 50 and $300 \mathrm{mg} \mathrm{L}^{-1}$. The TTF index of $\mathrm{Al}_{2}\left(\mathrm{SO}_{4}\right)_{3}$ reduced from $0.9 \mathrm{~s} . \mathrm{g}^{-1}$ MLSS in the control sample (without coagulant) to $0.3 \mathrm{s.g}-1 \mathrm{MLSS}$ in samples with $300 \mathrm{mg}$ $\mathrm{L}^{-1}$, which represent a TTF of $(131 \pm 7) \mathrm{s}$ and $(34 \pm$ 1) s, respectively. In general, a TTF less than $100 \mathrm{~s}$ indicates an easily filterable mixed liquor (Cótê, 2007; GE, 2009).

Despite the reduction in TTF index observed when the cationic polyacrylamide polymer concentrations

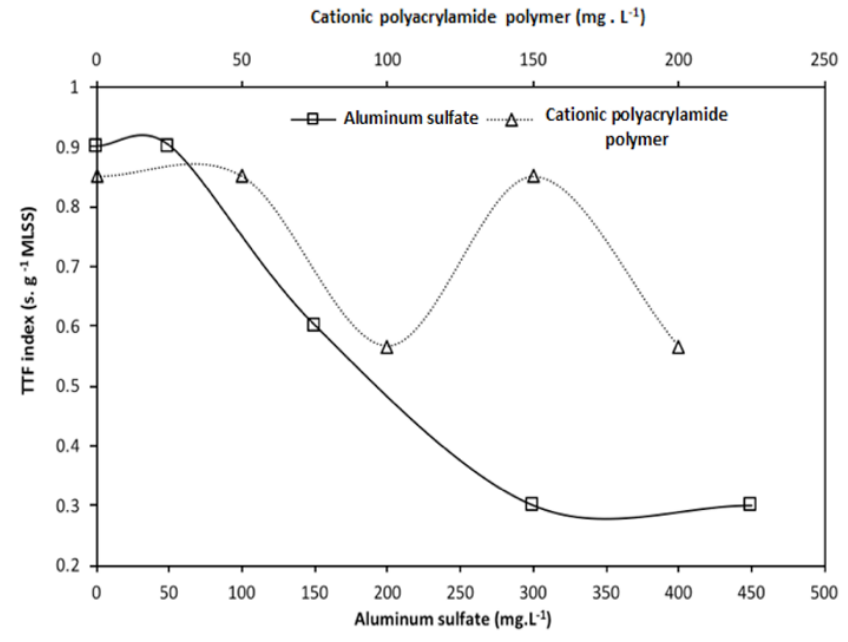

Figure 4. Time-to-Filter index at different flux enhancer concentrations.

were $100 \mathrm{mg} \mathrm{L}^{-1}$ and $200 \mathrm{mg} \mathrm{L}^{-1}$, the data were scattered and no relationship between them was evident. Under the optimized condition, the TTF was reduced from $(131 \pm 7) \mathrm{s}$ (control sample) to $(123 \pm 6)$ when the cationic polyacrylamide concentration was $200 \mathrm{mg}$ $\mathrm{L}^{-1}$, lower than the reduction achieved by $\mathrm{Al}_{2}\left(\mathrm{SO}_{4}\right)_{3}$ addition.

Although TTF reduction for the cationic polymers was less significant than for aluminum sulfate, the literature reports that their addition to mixed liquor can increase the floc sizes through a charge neutralization mechanism, which effectively mitigates the fouling. Furthermore, it is supposed that these chemicals could further enhance the entrapment of soluble EPS in flocs during the flocculation process (Ygiti et al., 2010; Dizge et al., 2011). This could indicate that TTF may not be enough to evaluate the filterability improvement of the sludge using flocculants, since TTF measures the effects of cake formation on sludge dewaterability only under static conditions.

Besides TTF, the effect of aluminum sulfate and the cationic polymer was also evaluated in the reduction of EPS (soluble and bound) and colloidal carbon. A reduction of $72.3 \%$ to $23.5 \%$ was verified in the colloidal/total ratio with a high correlation between the $\mathrm{Al}_{2}\left(\mathrm{SO}_{4}\right)_{3}$ concentrations used and the colloidal fraction reduction $\left(\mathrm{R}^{2}=0.9865\right)$ (Figure $\left.5 \mathrm{~A}\right)$. Instead, regarding the bound EPS, no bias was observed considering the proportion between colloidal and total fractions and different coagulant dosages (Figure 5B). 

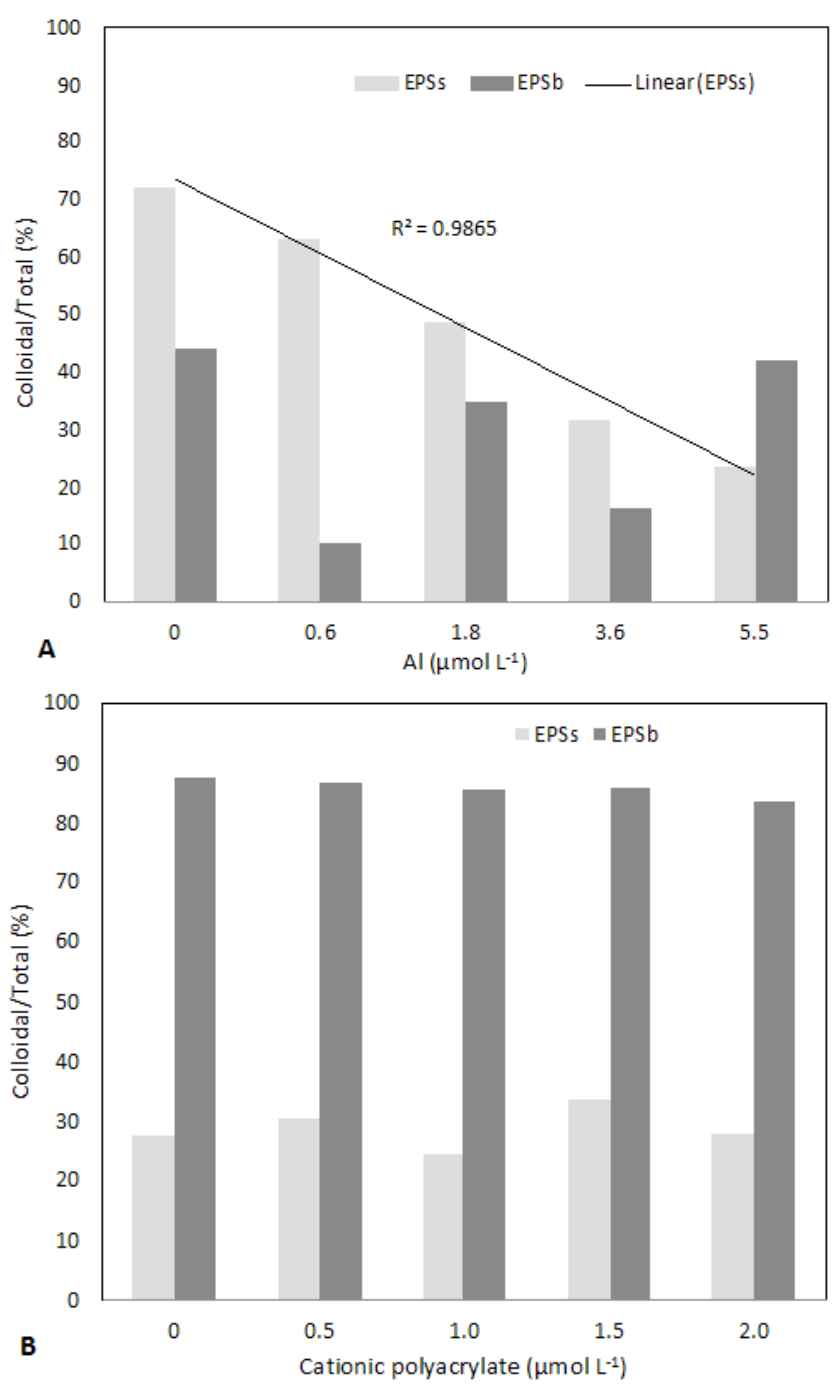

Figure 5. Colloidal/total ratio (\%) of the soluble EPS $\left(\mathrm{EPS}_{\mathrm{s}}\right)$ and bound EPS $\left(\mathrm{EPS}_{\mathrm{b}}\right)$ relation with aluminum (A) and cationic polyacrylamide (B) dosage.

Thus, the reduction of the sludge EPS, especially the colloidal fraction, as shown in Figure 5A, has a positive relation to fouling mitigation, as described by Mingu et al. (2009) and Shi et al. (2017). These studies indicated that EPS, such as carbohydrates and proteins, are able to increase the fluid dynamic viscosity and, consequently, reduce the permeate flux. In agreement with the investigations of Mishima and Nakajima (2009), a fouling reduction was verified after a chemical dosage of approximately $4.5 \mathrm{mg} \mathrm{L}^{-1}$ of aluminum salts, similar to Yang et al. (2011), who related a TMP reduction of $63 \%$ with addition of iron polychloride at $20 \mathrm{mg} \mathrm{L}^{-1}$.

Accordingly to Shi et al. (2017), polyacrylamide polymers have little tendency to reduce $\mathrm{EPS}_{\mathrm{BC}}$ in relation to $\mathrm{EPS}_{\mathrm{BT}}$, probably due to a bonding action on the organic colloidal matter, which results in a higher concentration of EPS $_{\mathrm{BT}}$. However, as presented in Figure 5B, it was not possible to confirm this behavior due to the complex nature of different biological systems, including the diverse EPS formation mechanisms and extraction strategies, generating uncertainties regarding EPS control through exogenous agent addition.

To evaluate the relationship between the variables TTF and soluble and bound EPS (total, colloidal and dissolved fractions, which was analyzed as TOC), correlation coefficients were calculated using the Pearson method (Table 5). For $\mathrm{Al}_{2}\left(\mathrm{SO}_{4}\right)_{3}$, a strong positive correlation was noted between TTF and EPS ${ }_{\mathrm{ST}}$, mainly in the colloidal fraction $\left(\mathrm{EPS}_{\mathrm{SC}}\right)$. Although of smaller magnitude, a correlation between TTF and EPS $_{\text {BT }}$ was also observed, but the correlation was higher for the dissolved fraction $\left(\mathrm{EPS}_{\mathrm{BD}}\right)$. Regarding the cationic polymer, a positive correlation was observed between the TTF and EPS in the colloidal fraction $\left(\mathrm{EPS}_{\mathrm{SC}}\right)$.

The effect of both chemicals on the liquor mixed filterability was evaluated in a stirred cell for the two best TTF results $\left(300 \mathrm{mg} \mathrm{L}^{-1}\right.$ of $\mathrm{Al}_{2}\left(\mathrm{SO}_{4}\right)_{3}$ and $200 \mathrm{mg}$ $\mathrm{L}^{-1}$ of cationic polymer). The results obtained for the aluminum sulfate coagulant, presented in Figure 6 as flux decrease and Fouling Index $\left(\mathrm{FI}_{30}\right)$, supported the TTF results since there was an improvement in the characteristics of the sludge that resulted in better filterability. However, the TTF results obtained for the cationic polymer did not represent any improvement of the liquor mixed filterability, but in the batch stirred filterability tests, the flux decreases for the polymer and aluminum sulfate were equivalent and showed lower flux decay compared to the control sample (untreated liquor mixed) (Figure 6A). Compared to the control sample, the $\mathrm{FI}_{30}$ improved from $25 \pm 7 \%$ to $32 \pm 4 \%$ and $32 \pm 3 \%$ for coagulant and flocculant, respectively.

Although results show improved mixed liquor filterability with the addition of coagulant and flocculant, there was a change in the relative contribution of the cake layer in fouling resistance. Without coagulant and flocculant, the relative cake layer contribution to fouling ( $\mathrm{Rc} / \mathrm{Rf})$ was higher

Table 5. Pearson correlation coefficients between time to filter (TTF) and EPS: total soluble EPS (EPS ${ }_{\mathrm{ST}}$ ), colloidal soluble EPS (EPS ${ }_{\mathrm{SC}}$ ), dissolved soluble EPS $\left(\mathrm{EPS}_{\mathrm{SD}}\right)$, total bound EPS (EPS $\left.{ }_{\mathrm{BT}}\right)$, colloidal bound EPS (EPS ${ }_{\mathrm{BC}}$ ) and dissolved bound EPS (EPS $\left.{ }_{\mathrm{BD}}\right)$.

\begin{tabular}{lcc}
\hline & \multicolumn{2}{c}{ TTF } \\
\cline { 2 - 3 } & $\begin{array}{c}\text { Aluminum } \\
\text { sulfate }\end{array}$ & $\begin{array}{c}\text { Cationic polyacrylamide } \\
\text { polymer }\end{array}$ \\
\hline EPSST $_{\mathrm{ST}}$ & $\mathbf{0 . 9 1 0}$ & -0.429 \\
$\mathrm{EPSSC}_{\mathrm{SC}}$ & $\mathbf{0 . 9 7 0}$ & $\mathbf{0 . 6 5 2}$ \\
$\mathrm{EPSS}_{\mathrm{S}}$ & -0.686 & -0.579 \\
$\mathrm{EPS}_{\mathrm{BT}}$ & $\mathbf{0 . 6 9 5}$ & 0.218 \\
EPS $_{\mathrm{BC}}$ & 0.149 & 0.325 \\
EPS $_{\mathrm{BD}}$ & $\mathbf{0 . 7 4 7}$ & -0.493 \\
\hline
\end{tabular}




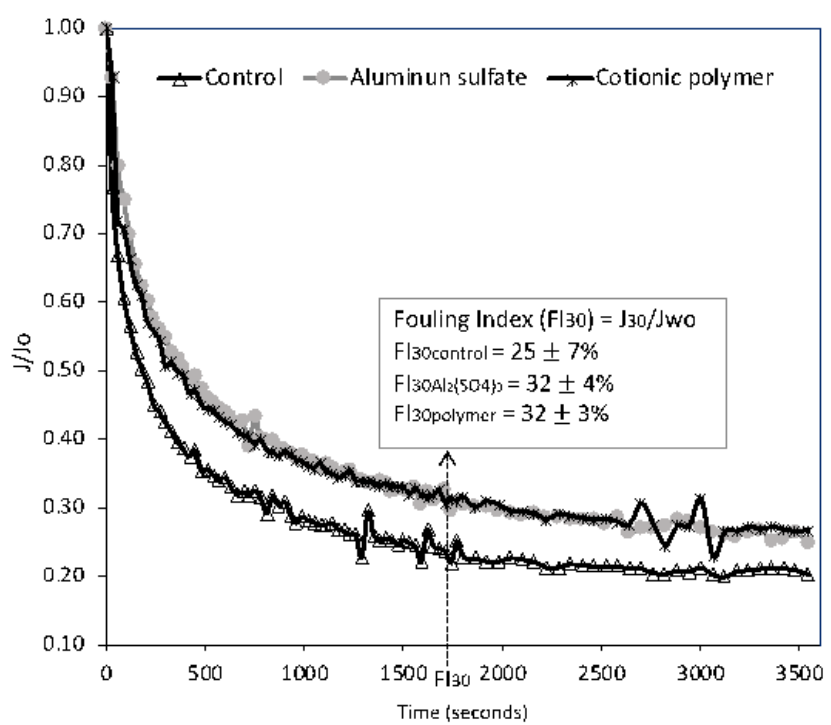

Figure 6. Flux decline during filterability tests and Fouling Index $\left(\mathrm{FI}_{30}\right)$.

than the adsorbed $(\mathrm{Ra} / \mathrm{Rf})$ and with the addition of coagulant and flocculant, the relative resistance of the adsorbed increased (Figure 7).

The increase of the $R_{A}$ contribution to fouling when aluminum sulfate was used may occur due to aluminum precipitation, which could result in membrane pore blocking. Precipitation of metal salts can lead to a severe membrane pore blocking in long-term MBR operation, imposing the necessity for complex physical and chemical cleaning process (Wang, 2014).

Regarding the polymer, although it favors the increase of floc size, the residual polymer can adsorb on the surface and pores of the membrane by electrostatic attraction caused by the charge difference. This may justify the increased contribution of adsorption to fouling.

Advantages in the use of the resistance in the series model is to characterize the relative significance of

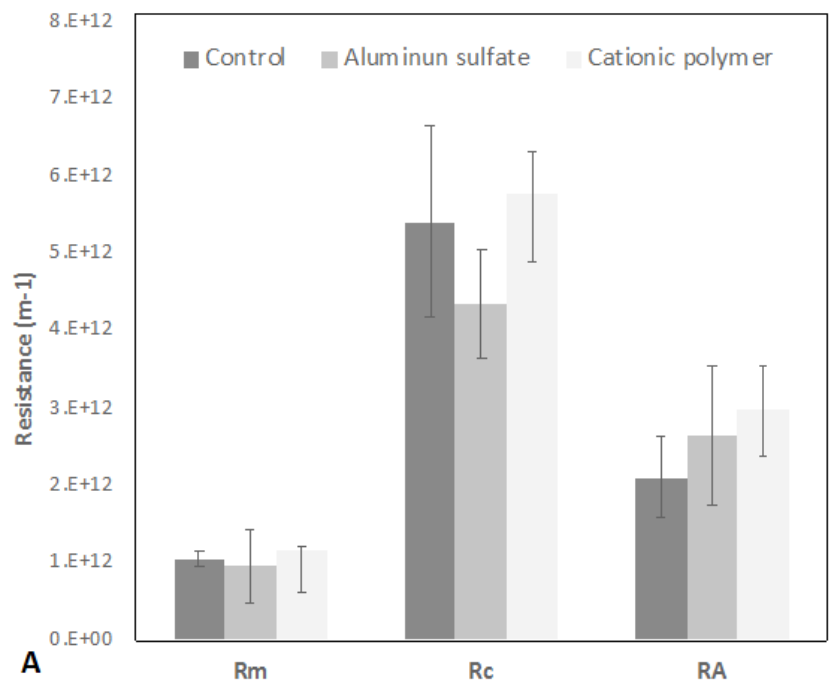

each resistance component in heterogeneous systems. However, although this model is widely used in the literature for fouling characterization, this should be used cautiously, because the additivity of individual resistances is questionable due to the complex nature of the sludge (Chang et al., 2009).

\section{Effect of the coagulant addition on phosphorus removal}

Regarding the orthophosphate removal (Figure 7 ), an increase was observed when the quantity of coagulant was raised. There was $87 \%$ orthophosphate removal with a concentration of $4.2 \mu \mathrm{mol} \mathrm{L}^{-1} \mathrm{Al}_{2}\left(\mathrm{SO}_{4}\right)_{3}$, resulting on a orthophosphate final concentration of $0.4 \mathrm{mg} \mathrm{L}^{-1}$. It was possible to identify that, from 0.6 to $1.2 \mu \mathrm{mol} \mathrm{L}^{-1}$ dosage of coagulant, there was a high orthophosphate removal rate, suggesting a firstorder relation over this dosage range. However, higher concentrations of $\mathrm{Al}_{2}\left(\mathrm{SO}_{4}\right)_{3}$ caused a decrease in the $\mathrm{pH}$ (less than 4.0 for the $4.2 \mu \mathrm{mol} \mathrm{L}^{-1}$ dosage), as a consequence of alkalinity consumption, resulting in an extreme condition for biological treatment in the MBR. Moreover, from 1.8 to $5.5 \mu \mathrm{mol} \mathrm{L} \mathrm{L}^{-1}$ concentration dosage, no meaningful increase in the orthophosphate removal rate was observed. Besides, the use of higher amounts of coagulant are not reasonable, as suggested by Song et al. (2008), which achieved 98\% of phosphorus removal in a lab-scale MBR with an aluminum dosage of $50 \mathrm{mg} \mathrm{L}^{-1}$.

The main purpose of cationic polymer usage in WWTP is to improve sludge filterability, as cited by Bolto et al. (2007) and Koseoglu et al. (2012). Differently from the results obtained with the addition of $\mathrm{Al}_{2}\left(\mathrm{SO}_{4}\right)_{3}$, the cationic polymer presented less than $1 \%$ of orthophosphate removal. This behavior can be explained by the polymer charge neutralization and bridge formation which happens between the anionic

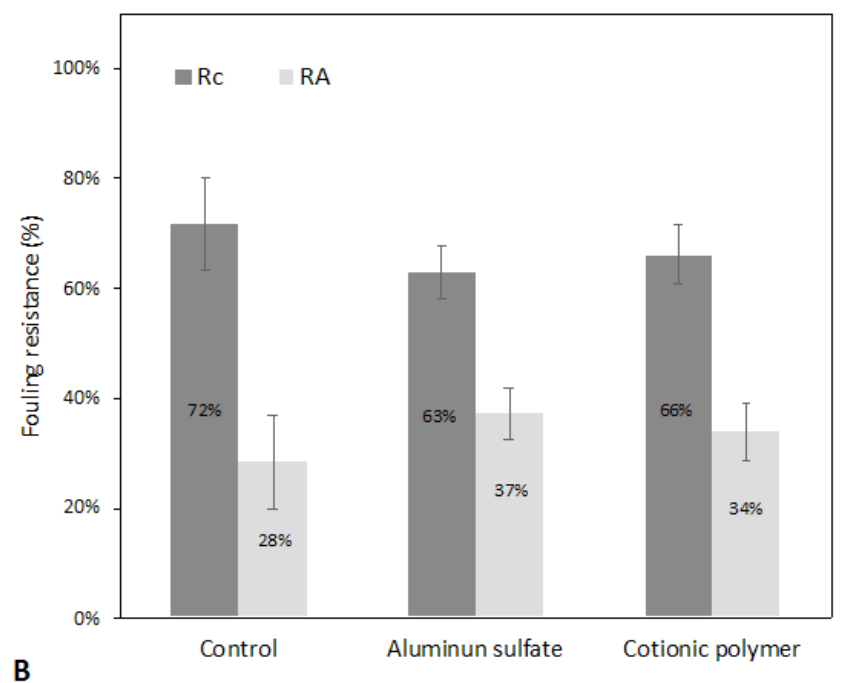

Figure 7. A - Membrane $\left(R_{M}\right)$, cake layer $\left(R_{C}\right)$ and adsorbed $\left(R_{A}\right)$ resistance; $B$ - relative contribution to the fouling resistance due to cake layer and adsorption. 


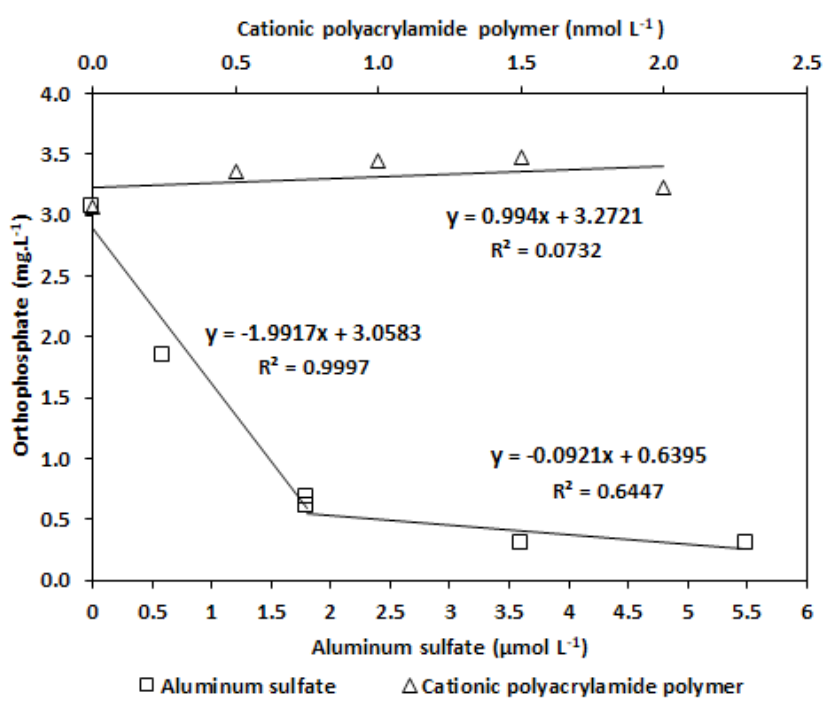

Figure 8. Orthophosphate removal relative to the coagulant and flocculant dosage.

charged organic matter and cationic polymer, described by Tchobanoglous (2003) and Bolto et al. (2007). Thus, no correlation could be observed between polymer dosage and orthophosphate removal, probably owing to charge neutralization from the solids/organic matter load in the sample evaluated.

\section{CONCLUSIONS}

This study evaluated the influence of aluminum sulfate $\left(\mathrm{Al}_{2}\left(\mathrm{SO}_{4}\right)_{3}\right)$ and a high molecular weight cationic polyacrylamide on the filterability properties of the mixed liquor from a SMBR pilot system, along with the reduction of the fouling effect and orthophosphate removal.

In the TTF experiments, improvements were only evident for aluminum sulfate, which decreased when $\mathrm{Al}_{2}\left(\mathrm{SO}_{4}\right)_{3}$ was added (TTF from $0.9 \mathrm{~s} \mathrm{~g}^{-1}$ MLSS to $0.3 \mathrm{~s} \mathrm{~g}^{-1}$ MLSS). Conversely, the cationic polymer changed the TTF from $0.9 \mathrm{~s} \mathrm{~g}^{-1}$ to $0.3 \mathrm{~s} \mathrm{~g}^{-1}$ MLSS, but no correlation was found between the polymer dosage and TTF results. A positive and significant correlation was observed between TTF reduction and colloidal EPS, indicating higher coagulation of the colloidal fraction of soluble EPS. In the batch filterability tests, the $\mathrm{FI}_{30}$ for the cationic polymer and aluminum sulfate improved from ( $32 \pm 3) \%$ and $(32 \pm 4 \%)$, respectively, to $(25 \pm 7) \%$. However, the addition of coagulant and flocculant increased the contribution of adsorption in relation to the cake layer, compared to the control system.

For orthophosphate, high removal was obtained when aluminum sulfate was used as coagulant, but no significant difference was observed when the concentration of the metal salt was increased from $1.8 \mu \mathrm{mol} \mathrm{L}^{-1}$ to $5.5 \mu \mathrm{mol} \mathrm{L}{ }^{-1}$, indicating that limited dosages are required to improve the orthophosphate removal in SMBR wastewater treatment plants. For the cationic polymer addition, no orthophosphate removal was observed, probably as a consequence of polymer charge neutralization caused by the anionic organic matter of the MLSS;

Finally, these results suggest that aluminum sulfate can improve the orthophosphate removal and both aluminum sulfate and cationic polyacrylamide can improve the sludge filterability. However, the use of the polymer and metal coagulants with membrane filtration should be carefully evaluated because it could enhance the potential for irreversible fouling in long-term operations.

\section{ACKNOWLEDGEMENTS}

The authors wish to thank the International Center on Water Reuse (CIRRA/USP) for their infrastructure contribution and the funding support by the National Council for Scientific and Technological Development (CNPq) (Grant number: 456619/2014-3).

\section{REFERENCES}

ABNT - Associação Brasileira de Normas Técnicas. NBR 12772: Água - Determinação de fósforo (1992).

APHA - American Public Health Association. Standard Methods for the Examination of Water and Wastewater, 21st Edition. American Public Health Association, Washington, DC (2012).

Bolto, B. Gregory, J. Organic polyelectrolytes in water treatment. Water Research, 41, 2301-2324 (2007). https://doi.org/10.1016/j.watres.2007.03.012

Chang, I.-S., Field, R., Cui, Z. Limitations of resistancein-series model for fouling analysis in membrane bioreactors: A cautionary note. Desalination and Water Treatment, 8, 31-36 (2009). https://doi. org/10.5004/dwt.2009.687

Chen, W., Gao, X., Xu, H., Cai, Y., Cui, J. Influence of extracellular polymeric substances (EPS) treated by combined ultrasound pretreatment and chemical re-flocculation on water treatment sludge settling performance. Chemosphere, 170, 196-206 (2017). https://doi.org/10.1016/j. chemosphere.2016.12.004

Côté, P. Future of membrane technoogy in worldwide sanitation. Proceedings of IWA Young Water, Professionals Conference, June 4-6. Berlin, Germany (2007).

Dizge, N., Koseoglu-Imer, D.Y., Karagunduz, A., Keskinler, B. Effects of cationic polyelectrolyte on filterability and fouling reduction of submerged membrane bioreactor MBR. J. Membrane Sci., 377, 175-181 (2011). https://doi.org/10.1016/j. memsci.2011.04.048 
Fan, F., Zhou, H., Husain, H. Identification of wastewater sludge characteristics to predict critical flux for membrane bioreactor processes. Water Res., 40, 205-212 (2006). https://doi.org/10.1016/j. watres.2005.10.037

GE Water \& Process Technologies. SERV-0042 Sludge Quality - Time to Filter Procedure, s.1.: GE Water \& Process Technologies (2009).

Gkotsis, P. K., Banti, C. D., Peleka, E. N., Zouboulis, A.I., Samaras, P. E. Fouling issues in membrane bioreactors (MBRs) for wastewater treatment: major mechanisms, prevention and control strategies. Processes, 2, 795-866, (2014). https:// doi.org/10.3390/pr2040795

Huyskens, C., de Wevera, H., Fovetc, Y., Wegmannc, U., Dielsa, L., Lenaertsb, S. Screening of novel MBR fouling reducers: benchmarking with known fouling reducers and evaluation of their mechanism of action. Separation and Purification Technology, 95, 49-57, (2012). https://doi.org/10.1016/j. seppur.2012.04.024

Iorhemen, O. T., Hamza, R. A., Tay, J. H. Membrane Bioreactor (MBR) Technology for Wastewater Treatment and Reclamation: Membrane Fouling. Membranes, 6, 1-29(2016). https://doi.org/10.3390/ membranes6020033

Judd, S. The MBR book: principles and applications of membrane bioreactors, in water and wastewater treatment. Elsevier (2006).

Karim, M. A., Mark, J. M. A. Preliminary Comparative Analysis of MBR and CAS Wastewater Treatment Systems. International Journal of Water and Wastewater Treatment, 3, 1-6 (2017). https://doi. org/10.16966/2381-5299.138

Khan, S. J., Visvanathan, C., Jegatheesan, V. Effect of powdered activated carbon (PAC) and cationic polymer on biofouling mitigation in hybrid MBRs. Bioresource Technology, 113, 165-168 (2012). https://doi.org/10.1016/j.biortech.2011.12.107

Koseoglu, H., Yigit, N.O., Civelekoglu, G., Harman, B.I., Kitis, M. Effects of chemical additives on filtration and rheological characteristics of MBR sludge. Bioresource Technology, 117, 48-54 (2012). https://doi.org/10.1016/j.biortech.2012.04.067

Krzeminski, P., Leverette, L., Malamis, S., Katsou, E., Mebrane bioreactors - A review on recent developments in energy reduction, fouling control, novel configurations, LCA and market prospects. Journal of Membrane Science, 527, 207-227 (2017). https://doi.org/10.1016/j.memsci.2016.12.010

Le-Clech, P. Membrane bioreactors and their uses in wastewater treatments. Appl Microbiol. Biotechnol., 88, 1253-1260 (2010). https://doi. org/10.1007/s00253-010-2885-8

Lee, J. C., Kim, J. S., Kang, I. J., Cho, M. H., Park, P. K., Lee, C. H. Potential and Limitations of alum and zeolite addition to improve the performance of a submerged membrane bioreactor. Water Science and Technology, 43, 59-66 (2001). https://doi. org/10.2166/wst.2001.0667

Lin, H., Zhang, M., Wang, F., Meng, F., Liao, B. Q., Hong, H., Chen, J., Gao, W. A critical review of extracellular polymeric substances (EPSs) in membrane bioreactors: characteristics, roles in membrane fouling and control strategies. Journal of Membrane Science, 460, 110-125 (2014). https:// doi.org/10.1016/j.memsci.2014.02.034

Macêdo, J. A. B. Águas e Águas. 3.ed. Belo Horizonte. 1044 p (2007).

Mbaeze, M. C., Agbazue, V. E., Orjioke, N. M. Comparative Assessment of Performance of Aluminium Sulphate (Alum) and Ferrous Sulphate as Coagulants in Water Treatment. Mod Chem. Appl., 5, 1-14 (2017).

Mingu, K., Nakhla, G. Comparative studies on membrane fouling between two membrane-based biological nutrient removal systems. Journal of Membrane Science, 331, 91-99 (2009). https://doi. org/10.1016/j.memsci.2009.01.018

Mishima, I., Nakajima, J. Control of membrane fouling in membrane bioreactor process by coagulant addition. Water Science and Technology, 59, 12551262 (2009). https://doi.org/10.2166/wst.2009.090

Monclús, H., Sipma, J., Ferrero, G., Rodriguez-Roda, I., Comas, J. Biological nutrient removal in an MBR treating municipal wastewater with special focus on biological phosphorus removal. Bioresource Technology, 101, 3984-3991 (2010). https://doi. org/10.1016/j.biortech.2010.01.038

Morgan, J.W., Forster, C.F., Evison, L. A comparative study of the nature of biopolymers extracted from anaerobic and activated sludges. Water Res., 24, 743-750, (1990). https://doi.org/10.1016/00431354(90)90030-A

Schlosser, C. A., Strzepek, K., Gao, X., Fant, C., Blanc, É., Paltsev, S., Jacoby, H., Reilly, J., Gueneau, A. The future of global water stress: An integrated assessment. Earth's Future, 2, 341-361 (2014). https://doi.org/10.1002/2014EF000238

Shi, Y., Huang, J., Zeng, G., Gu, Y., Chen, Y., Hu, Y., Tang, B., Zhou, J., Yang, Y., Shi, L. Exploiting extracellular polymeric substances (EPS) controlling strategies for performance enhancement of biological wastewater treatments: An overview. Chemosphere, 180, 396-411 (2017). https://doi. org/10.1016/j.chemosphere.2017.04.042

Song, K. G., Kim, Y., Ahn, K. H. Effect of coagulant addition on membrane fouling and nutrient removal in a submerged membrane bioreactor. Desalination, 221, 467-474 (2008). https://doi.org/10.1016/j. desal.2007.01.107

Subtil, E. L., Hespanhol, I., Mierzwa, J. C. Submerged Membrane Bioreactor (sMBR): a promising 
alternative to wastewater treatment for water reuse. Revista Ambiente \& Água, 8, 129-142 (2013). https://doi.org/10.4136/ambi-agua.1230

Subtil, E. L., Hespanhol, I., Silva, M. V. Um novo paradigma para o planejamento do saneamento: do tratamento de esgoto à recuperação sustentável de recursos. In: Waldir Mantovani; Andrea de Oliveira Cardoso; Roseli Frederigi Benassi; Eduardo Lucas Subtil. (Org.). Ciência e Tecnologia Ambiental: conceitos e perspectivas. 1ed.: v. 1, p. 319-341 (2016).

Subtil, E. L., Hespanhol, I., Mierzwa, J. C. Comparison between a conventional membrane bioreactor (C-MBR) and a biofilm membrane bioreactor (BF-MBR) for domestic wastewater treatment. Brazilian Journal of Chemical Engineering, 31, 683 - 691 (2014). https://doi.org/10.1590/01046632.20140313s00002890

Sun, F.-Y., Wang, X.-M., Li, X.-Y. An innovative membrane bioreactor (MBR) system for simultaneous nitrogen and phosphorus removal. Process Biochemistry, 48, 1749-1756 (2013). https://doi.org/10.1016/j.procbio.2013.08.009

Tchobanoglous, G., Burton, F. L., Stensel, H. D. Wastewater engineering: treatment, disposal and reuse. 4th Edition New York: McGraw-Hill, 1819, (2013).

Teychene, B., Guigui, C., Cabassud, C. Engineering of an MBR supernatant fouling layer by fine particles addition: A possible way to control cake compressibility. Water Reseach, 45, 2060-2072 (2011). https://doi.org/10.1016/j. watres.2010.12.018

Verstraete, W., Clauwaert, P., Vlaeminck, S. Used water and nutrients: recovery perspectives in a 'panta rhei' context. Bioresource Technology, 215, 199-208 (2016). https://doi.org/10.1016/j. biortech.2016.04.094

Wang, Z., Wu, Z., Tang, S. Extracellular polymeric substances (EPS) properties and their effects on membrane fouling in a submerged membrane bioreactor. Water Research, 43, 2504-2512 (2009). https://doi.org/10.1016/j.watres.2009.02.026

Wang, Z., Ma, J., Tang, C. Y., Kimura, K., Wang, Q., Han, X. Membrane cleaning in membrane bioreactors: a review. Journal of Membrane Science, 468, 276-307 (2014). https://doi.org/10.1016/j. memsci.2014.05.060

Wu, B., Wang, Y., Lim, W., Chew, J. W., Fane, A. G., Liu, Y. Enhanced performance of submerged hollow fibre microfiltration by fluidized granular activated carbon. Journal of Membrane Science, 499, 47-55 (2016). https://doi.org/10.1016/j. memsci.2015.10.050

Wu, B., Zamani, F., Lim, W., Liao, D., Wang, Y., Liu, Y., Chew, J. W., Fane, A. G. Effect of mechanical scouring by granular activated carbon (GAC) on membrane fouling mitigation. Desalination, 403, 80-87 (2017). https://doi.org/10.1016/j. desal.2015.12.003

Wu, J., Chen, F., Huang, X., Geng, W., Wen, X. Using inorganic coagulants to control membrane fouling in a submerged membrane bioreactor. Desalination, 197, 124-136 (2006). https://doi.org/10.1016/j. desal.2005.11.026

Yang, X. L., Song, H. L., Chen, M., Cheng, B. Characterizing membrane foulants in MBR with addition of polyferric chloride to enhance phosphorus removal. Bioresource Technology, 102, 9490-9496 (2011). https://doi.org/10.1016/j. biortech.2011.07.105

Yigit, N. O, Civelekoglu, G., Cinar, O., Kitis, M. Filterability of membrane bioreactor (MBR) sludge: impacts of polyelectrolytes and mixing with conventional activated sludge. Water Science and Technology, 61, 659-669 (2010). https://doi. org/10.2166/wst.2010.869

Yoon, S.-H. Membrane Bioreactor Processes: Principles and Applications. 1st Edition, 452 p. CRC Press (2015). https://doi.org/10.1201/b18631

Zang, H. F., Sun, B. S., Zhao, X. H., Gao, Z. H. Effect of ferric chloride on fouling in membrane bioreactor. Separation and Purification Technology, 63, 341-347 (2008). https://doi.org/10.1016/j. seppur.2008.05.024

Zhang, Z., Wang, Y., Leslie, G. L., Waite, T. D. Effect of ferric and ferrous iron addition on phosphorus removal and fouling in submerged membrane bioreactors. Water Research, 69, 210-222 (2015). https://doi.org/10.1016/j.watres.2014.11.011 
